\title{
Whole-genome sequence of a novel, mangrove-derived streptomycete, Streptomyces malaysiense strain MUSC 136 ${ }^{\mathrm{T}}$
}

\author{
Hooi-Leng Ser ${ }^{1}$, Wen-Si Tan², Wai-Fong Yin ${ }^{3}$, Kok-Gan Chan ${ }^{3,4}$, Learn-Han Lee ${ }^{1 *}$ \\ ${ }^{1}$ Novel Bacteria and Drug Discovery (NBDD) Research Group, Microbiome and Bioresource Research Strength (MBRS), \\ Jeffrey Cheah School of Medicine and Health Sciences, Monash University Malaysia, Bandar Sunway, 47500 Selangor \\ Darul Ehsan, Malaysia \\ ${ }_{2}^{2}$ Illumina Singapore Pte Ltd, Woodlands Industrial Park E1, Singapore \\ ${ }^{3}$ Division of Genetics and Molecular Biology, Institute of Biological Sciences, Faculty of Science, University of Malaya, \\ 50603 Kuala Lumpur, Malaysia \\ ${ }^{4}$ International Genome Centre, Jiangsu University, 212013 Zhenjiang, China
}

\begin{abstract}
Since the discovery of streptomycin from Streptomyces griseus in the early 1940s, streptomycetes from various environments have been studied thoroughly for the ability to produce bioactive compounds including antibacterial, antioxidant, anticancer, antifungal as well as immunomodulatory properties. Previously identified as a novel strain from a mangrove forest in Malaysia, Streptomyces malaysiense MUSC $136^{\mathrm{T}}$ was selected for genome sequencing to explore its genomic potential. The genomic size comprises of $7,963,326$ bp with a $\mathrm{G}+\mathrm{C}$ content of $72.2 \%$ and a total of 6,614 proteincoding genes. As an attempt to investigate the types of biosynthetic gene cluster present in the MUSC $136^{\mathrm{T}}$, the whole genome sequence was analyzed with a bioinformatics tool, antibiotics \& Secondary Metabolite Analysis Shell (antiSMASH). Using the "strict" prediction method, a total of seven biosynthetic gene clusters which displayed similarity of more than $80 \%$ to known gene clusters including ectoine, geosmin as well as desferrioxamine. Apart from emphasizing the importance of streptomycetes from unique environments like mangrove forest, the current study serves as a foundation for future studies on the role of specific genes present in biosynthetic gene clusters which enables the exploitation of MUSC $136^{\mathrm{T}}$ to synthesize important and valuable compounds.
\end{abstract}

Keywords: Streptomyces; cancer; cytotoxic; mangrove; genome; MUSC 136 ${ }^{\mathrm{T}}$; actinobacteria

*Correspondence: Learn-Han Lee, Novel Bacteria and Drug Discovery (NBDD) Research Group, Microbiome and Bioresource

Received: $8^{\text {th }}$ November 2020

Accepted: $10^{\text {th }}$ December 2020

Published Online: $24^{\text {th }}$ December 2020 Research Strength, Jeffrey Cheah School of Medicine and Health Sciences, Monash University Malaysia, Bandar Sunway, 47500 Selangor Darul Ehsan, Malaysia; lee.learn.han@monash.edu

Citation: Ser H-L, Tan W-S, Yin W-F et al. Whole-genome sequence of a novel, mangrove-derived streptomycete, Streptomyces Malaysiense strain MUSC 136 ${ }^{\mathrm{T}}$. Prog Drug Discov Biomed Sci 2020; 3(1): a0000145. https://doi.org/10.36877/ pddbs.a0000145.

\section{Short Introduction}

Ubiquitous in nature, streptomycetes have growth advantages compared to other microbes, given that their unique life cycle and ability to form spores when conditions are not favorable for growth ${ }^{[1-8]}$. Additionally, these filamentous microbes can produce compounds of various structures possessing bioactivities such as antioxidant, anticancer, antibacterial, and so forth ${ }^{[1,9-20]}$. The discovery of bioactive streptomycetes from unique environments like the deep sea, cave, and mangrove forest has proven successful ${ }^{[21-33]}$. During a screening program for bioactive Actinobacteria (including those belonging to genus Streptomyces) in Malaysia, Streptomyces malaysiense MUSC $136^{\mathrm{T}}$ was recovered from a mangrove forest in Tanjung Lumpur location on the East Coast of Peninsular Malaysia ${ }^{[34,35]}$. The polyphasic study on the strain showed that its 16S rRNA gene showed high similarities with other members of Streptomyces genus, including Streptomyces misionensis NBRC $13063^{\mathrm{T}}$ (99.6\%), Streptomyces phaeoluteichromatogenes NRRL $5799^{\mathrm{T}}(99.6 \%)$, and Streptomyces rutgersensis NBRC $12819^{\mathrm{T}}(98.9 \%)$. Nonetheless, DNA-DNA hybridization (DDH) results demonstrated that the strain is indeed a novel strain belonging to this genus as its values are well below the recommended delineation value (i.e., $70 \%$ ) when compared to three of the selected type strains (DDH value ranged from $22.7-47.5 \%)^{[35,36]}$. The type strain for MUSC $136^{\mathrm{T}}$ is available at two culture collection centres with the accession of $\left(=\right.$ DSM $100712^{\mathrm{T}}=$ MCCC $\left.1 \mathrm{~K} 01246^{\mathrm{T}}\right)$. In our previous study, fermentative extracts of MUSC $136^{\mathrm{T}}$ exhibited potent cytotoxic activities against several human colon cancer cell lines, with cell survival recorded to be less than 50\% (extract dose: 400 $\mu \mathrm{g} / \mathrm{ml})^{[35]}$. In turn, these results prompted further mining into its genomic sequence, particularly the detection of 
gene clusters related to bioactive compounds production.

\section{Data description}

Whole genomic DNA of MUSC $136^{\mathrm{T}}$ was extracted using a commercial kit, Masterpure ${ }^{\mathrm{TM}}$ DNA purification kit (Epicentre, Illumina Inc., Madison, WI, USA) before RNase treatment (Qiagen, USA) ${ }^{[37-40]}$. DNA library was constructed with Nextera DNA Sample Preparation kit (Nextera, USA), while the library quality was evaluated by Bioanalyzer 2100 high sensitivity DNA kit (Agilent Technologies, Palo Alto, CA). Paired-end sequencing was performed on Illumina MiSeq platform with MiSeq Reagent Kit $2(2 \times 250$ bp; Illumina Inc., Madison, WI, USA $)^{[41,42]}$. After trimming, the paired-end reads were de novo assembled on CLC Genomics Workbench version 7 (CLC bio, Denmark), which resulted in 235 contigs and a $\mathrm{N}_{50}$ contig size of approximately $123,175 \mathrm{bp}$. The genome size of MUSC $136^{\mathrm{T}}$ comprised 7,963,326 bp, with an average coverage of 95.0 -fold and $\mathrm{G}+\mathrm{C}$ content of $72.2 \%$. The genome sequence of MUSC $136^{\mathrm{T}}$ has been deposited at DDBJ/EMBL/GenBank under accession of LBDA02000000. The version described in this paper is the second version.

Table 1. General genomic features of Streptomyces malaysiense MUSC 136

\begin{tabular}{|c|c|}
\hline & Streptomyces malaysiense MUSC $136^{\mathrm{T}}$ \\
\hline Genome size (bp) & $7,963,326$ \\
\hline Contigs & 235 \\
\hline Contigs $\mathrm{N}_{50}(\mathrm{bp})$ & 123,175 \\
\hline $\mathrm{G}+\mathrm{C}$ content $\%$ & 72.2 \\
\hline Genome coverage & $95.0 \mathrm{x}$ \\
\hline Protein coding genes & 6,614 \\
\hline tRNA & 67 \\
\hline rRNA $(5 \mathrm{~S}, 16 \mathrm{~S}, 23 \mathrm{~S})$ & $1,1,1$ \\
\hline
\end{tabular}

The assembled genome was annotated using Rapid Annotation using Subsystem Technology (RAST) and NCBI Prokaryotic Genome Annotation Pipeline
(PGAP) $^{[43,44]}$. Prodigal (Version 2.6) was used to perform gene prediction, while ribosomal RNA (rRNA) and transfer RNA (tRNA) were predicted using RNAmmer and tRNAscan SE version 1.21, respectively ${ }^{[45-47]}$. This analysis revealed 6,614 protein-coding genes, along with a total of 67 tRNA and three rRNA genes. Based on RAST annotation, most of the protein-coding genes were shown to be involved in amino acids and derivatives metabolism (9.47\%), followed by carbohydrates metabolism (7.19\%) and protein metabolism subsystems (4.60\%) (Figure 1). Further analysis of antibiotics \& Secondary Metabolite Analysis Shell (antiSMASH) detected the presence of 36 biosynthetic gene clusters in MUSC $136^{\mathrm{T}}$ genome using

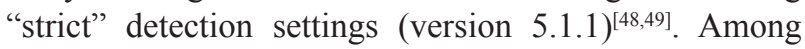
these biosynthetic gene clusters, seven of them displayed more than $80 \%$ similarities to known gene clusters related to terpene, lantipeptide, ectoine, thiopeptide, and siderophore production. Besides being an important drug to treat iron overload, the potential use of the siderophore, desferrioxamine, in combatting chronic diseases like neurodegenerative diseases and cancer were also examined over these years ${ }^{[50-53]}$. Complementing previous findings from chemical profiling studies, MUSC $136^{\mathrm{T}}$ indeed produces desferrioxamine, which is suggested to be responsible for the cytotoxicity observed against colon cancer cell lines ${ }^{[35]}$. As a matter of fact, iron metabolism has been implicated as a potential therapeutic target in cancer treatment as cancer cells typically have higher iron requirements compared to healthy, normal cells ${ }^{[54-60]}$. By reducing the availability of iron, it is possible to reduce oxidative damage, which is often seen in colorectal cancer, while at the same time preventing colon cancer cell growth and survival. With the identification of biosynthetic gene cluster responsible for desferrioxamine within the genome of MUSC $136^{\mathrm{T}}$, future works involving modification of gene expression to enhance the production of this valuable compound as well as other pharmaceutically important compounds like ectoine as cytoprotectant against radiation and inflammation ${ }^{[61-70]}$ as well as lantipeptides which can act as potent antibiotics to prevent deadly infectious diseases ${ }^{[71-81]}$.

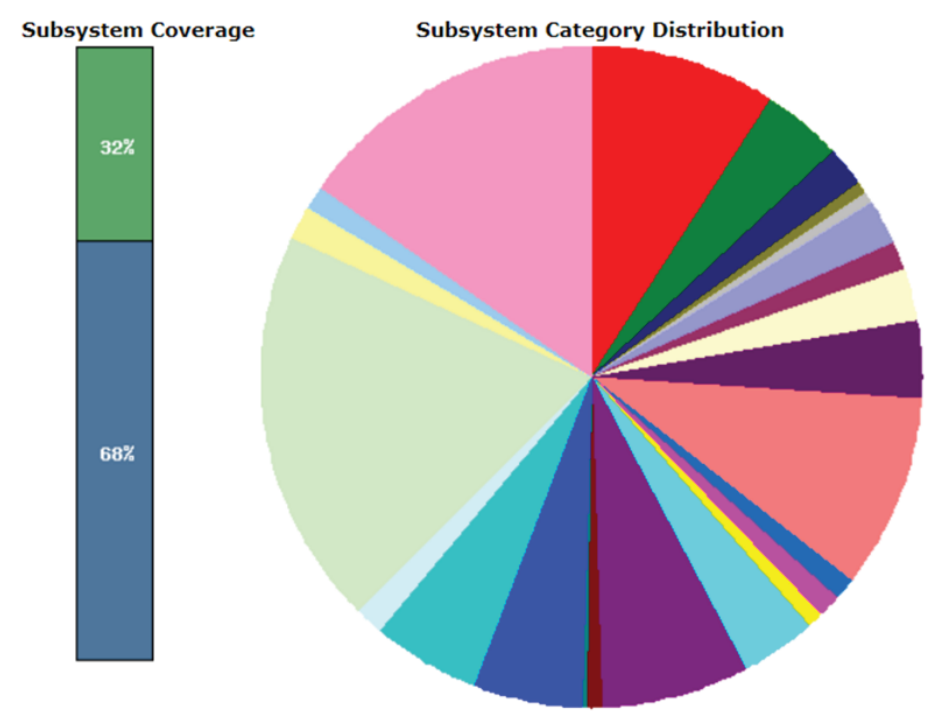

Subsystem Feature Counts

Cofactors, Vitamins, Prosthetic Groups, Pigments (319)

$\boxplus$ Cell Wall and Capsule (134)

$\boxplus$ Virulence, Disease and Defense (64)

$\boxplus$ Potassium metabolism (21)

$\boxplus$ Photosynthesis (0)

$\boxplus$ in Miscellaneous (18)

(8)

田 Membrane Transport (76)

$\boxplus$ Iron acquisition and metabolism (51)

$\boxplus \quad$ RNA Metabolism (83)

$\boxplus$ Nucleosides and Nucleotides (137)

$\boxplus$ Protein Metabolism (326)

$\boxplus$ Cell Division and Cell Cycle (36)

$\boxplus$ Motility and Chemotaxis (2)

$\boxplus$ Regulation and Cell signaling (42)

$\boxplus$ Secondary Metabolism (25)

$\boxplus$ DNA Metabolism (127)

$\boxplus$ Fatty Acids, Lipids, and Isoprenoids (241)

$\boxplus$ Nitrogen Metabolism (32)

$\boxplus$ Dormancy and Sporulation (11)

$\boxplus$ Respiration (179)

$\boxplus$ Stress Response (185)

Metabolism of Aromatic Compounds (43)

$\boxplus$ Amino Acids and Derivatives (672)

$\boxplus$ Amino Acids and Deriva

$\boxplus \quad$ Sulfur Metabolism (53)

田 Phosphorus Metabolis 


\section{Conflict of Interest}

The authors declare that there is no conflict of interest in this work.

\section{Acknowledgements}

This work was supported by the University of Malaya for High Impact Research Grant (UM-MOHE HIR Nature Microbiome Grant No. H-50001-A000027 and No. A000001-5001) and PPP Grant (PG090-2015B) awarded to K-GC, with FRGS Grant (FRGS/1/2019/SKK08/ MUSM/02/7) and External Industry Grant (Biotek Abadi Vote No. GBA-808138 and GBA-808813) awarded to L-HL.

\section{Reference}

1. Petitti DB, Crooks VC, Buckwalter JG, et al. Blood pressure levels before dementia. Arch Neurol 2005; 62(1): 112-116.

2. American Diabetes Association. Diabetes update. Nursing 2003; Suppl: 19-20, 24.

3. National Institutes of Health (US). End-of-life care. National Institutes of Health statement on the state of the science. AWHONN Lifelines 2005; 9(1): 15-22

4. Massone L, Borghi S and Pestarino A. Localisations palmaires purpuriques de la dermatite herpetiforme (French) [Purpuric palmar sites of dermatitis herpetiformis]. Ann Dermatol Venerol 1987; 114(12): 1545-1547.

5. Ohlsen MM, Horne AM and Lowe CF. Group counseling. New York: Holt, Rinehart, and Winston; 1988. p. 416

6. Riffenburgh RH. Regression and correlation methods. $2^{\text {nd }}$ ed. In Statistics in medicine. Amsterdam, Netherlands: Elsevier Academic Press; 2006. p. 447-486.

7. Rojko JL and Hardy WD Jr. Feline leukemia virus and other retroviruses. $3^{\text {rd }}$ ed. In: Sherding RG (editors). The cat: Diseases and clinical management. New York: Churchill Livingstone; 1989. p. 229-332.

8. Berdy J. Bioactive microbial metabolites. J Antibiotics 2005; 58(1):126.

9. Watve MG, Tickoo R, Jog MM, et al. How many antibiotics are produced by the genus Streptomyces?. Arch Microbiol 2001; 176(5): 386-390.

10. Ser HL, Palanisamy UD, Yin WF, et al. Presence of antioxidative agent, Pyrrolo [1, 2-a] pyrazine-1, 4-dione, hexahydro-in newly isolated Streptomyces mangrovisoli sp. nov. Front Microbiol 2015; 6 : 854.

11. Ali A, Khajuria A, Sidiq T, et al. Modulation of LPS induced inflammatory response by Lawsonyl monocyclic terpene from the marine derived Streptomyces sp. Immunol Lett 2013; 150(1-2) :7986.

12. Law JW, Ser HL, Duangjai A, et al. Streptomyces colonosanans sp. nov., a novel actinobacterium isolated from Malaysia mangrove soi exhibiting antioxidative activity and cytotoxic potential against human colon cancer cell lines. Front Microbiol 2017; 8: 877.

13. Dharmaraj S. Marine Streptomyces as a novel source of bioactive substances. World J Microbiol Biotech 2010; 26(12): 2123-2139.

14. Ward AC and Allenby NE. Genome mining for the search and discovery of bioactive compounds: the Streptomyces paradigm. FEMS Microbiol Lett 2018; 365(24): fny240.

15. Ser HL, Tan LT, Law JW, et al. Focused review: cytotoxic and antioxidant potentials of mangrove-derived Streptomyces. Front Microbiol 2017; 8: 2065.

16. Cot M, Ray A, Gilleron M, et al. Lipoteichoic acid in Streptomyces hygroscopicus: structural model and immunomodulatory activities. PLoS One 2011; 6(10): e26316.

17. Balasubramanian S, Othman EM, Kampik D, et al. Marine spongederived Streptomyces sp. SBT343 extract inhibits staphylococcal biofilm formation. Front Microbiol 2017; 8: 236.

18. Law JW, Pusparajah P, Ab Mutalib NS, et al. A review on mangrove actinobacterial diversity: the roles of Streptomyces and novel species discovery. Prog Microbes Mol Biol 2019; 2(1)

19. Quinn GA, Banat AM, Abdelhameed AM, et al. Streptomyces from traditional medicine: sources of new innovations in antibiotic discovery. J Med Microbiol 2020; 69(8): 1040.

20. Law JW, Ser HL, Khan TM, et al. The potential of Streptomyces as biocontrol agents against the rice blast fungus, Magnaporthe oryzae (Pyricularia oryzae). Front Microbiol 2017; 8: 3.

21. Núñez-Montero K, Lamilla C, Abanto M, et al. Antarctic Streptomyces fildesensis So13. 3 strain as a promising source for antimicrobials discovery. Sci Rep 2019; 9(1): 1-3.
22. Lee LH, Goh BH and Chan KG. Actinobacteria: Prolific producers of bioactive metabolites. Front Microbiol 2020; 11 .

23. Clardy J, Fischbach MA and Walsh CT. New antibiotics from bacterial natural products. Nat Biotech 2006; 24(12): 1541-1550.

24. Tan LT, Chan KG, Lee LH, et al. Streptomyces bacteria as potential probiotics in aquaculture. Front Microbiol 2016; 7: 79.

25. Kemung HM, Tan LT, Chan KG, et al. Investigating the antioxidant potential of Streptomyces sp. MUSC 11 from mangrove soil in Malaysia. Prog Drug Dis Biomed Sci 2019; 2(1)

26. Xiong ZQ, Wang JF, Hao YY, et al. Recent advances in the discovery and development of marine microbial natural products. Mar Drugs 2013; 11(3): 700-717

27. Ser HL, Law JW, Chaiyakunapruk N, et al. Fermentation conditions that affect clavulanic acid production in Streptomyces clavuligerus: systematic review. Front Microbiol 2016; 7: 522.

28. Nimaichand S, Devi AM, Tamreihao K, et al. Actinobacterial diversity in limestone deposit sites in Hundung, Manipur (India) and their antimicrobial activities. Front Microbiol 2015; 6: 413.

29. Subramani R and Aalbersberg W. Marine actinomycetes: an ongoing source of novel bioactive metabolites. Microbiol Res 2012; 167(10): $571-580$.

30. Maciejewska M, Całusińska M, Cornet L, et al. High-throughpu sequencing analysis of the actinobacterial spatial diversity in moonmilk deposits. Antibiotics 2018; 7(2): 27.

31. Kemung HM, Tan LT, Chan KG, et al. Streptomyces sp. strain MUSC 125 from mangrove soil in malaysia with anti-mrsa, anti-biofilm and antioxidant activities. Molecules 2020; 25(15): 3545

32. Syiemiong D and Jha DK. Antibacterial potential of Actinobacteria from a Limestone Mining Site in Meghalaya, India. J Pure Appl Microbiol 2019; 13(2): 789-802.

33. Bubici G. Streptomyces spp. as biocontrol agents against Fusarium species. CAB Rev. 2018; 13: 050 .

34. Azman AS, Othman I, S Velu S, et al. Mangrove rare actinobacteria: taxonomy, natural compound, and discovery of bioactivity. Front Microbiol 2015; 6: 856

35. Rangseekaew P and Pathom-Aree W. Cave actinobacteria as producers of bioactive metabolites. Front Microbiol 2019; 10: 387.

36. Maciejewska M, Adam D, Martinet L, et al. A phenotypic and genotypic analysis of the antimicrobial potential of cultivable Streptomyces isolated from cave moonmilk deposits. Front Microbiol 2016; 7: 1455.

37. Azman AS, Othman I, Fang CM, et al. Antibacterial, anticancer and neuroprotective activities of rare Actinobacteria from mangrove forest soils. Indian J Microbiol 2017; 57(2): 177-187.

38. Lee LH, Chan KG, Stach J, et al. The search for biological active agent(s) from actinobacteria. Front Microbiol 2018; 9: 824

39. Law JW, Pusparajah P, Ab Mutalib NS, et al. A review on mangrove actinobacterial diversity: the roles of Streptomyces and novel species discovery. Prog Microbes Mol Biol 2019; 2(1)

40. Ser HL, Yin WF, Chan KG, et al. Antioxidant and cytotoxic potential of Streptomyces gilvigriseus MUSC $26^{\mathrm{T}}$ isolated from mangrove soil in Malaysia. Prog Microbes Mol Biol 2018; 1(1).

41. Lee LH, Zainal N, Azman AS, et al. Diversity and antimicrobial activities of actinobacteria isolated from tropical mangrove sediments in Malaysia. Sci World J 2014; 2014.

42. Ser HL, Palanisamy UD, Yin WF, et al. Streptomyces malaysiense sp. nov.: a novel Malaysian mangrove soil actinobacterium with antioxidative activity and cytotoxic potential against human cancer cell lines. Sci Rep 2016; 6(1): 1-2.

43. Meier-Kolthoff JP, Klenk HP and Göker M. Taxonomic use of DNA $\mathrm{G}+\mathrm{C}$ content and DNA-DNA hybridization in the genomic age. Int $J$ Syst Evol Microbiol 2014; 64(2): 352-356.

44. Ser HL, Tan WS, Ab Mutalib NS, et al. Genome sequence of Streptomyces pluripotens MUSC $135^{\mathrm{T}}$ exhibiting antibacterial and antioxidant activity. Marine Gen 2015; 24: 281-283

45. Ser HL, Law JW, Tan WS, et al. Genome sequence of bioactive streptomycete isolated from mangrove forest in East Malaysia, Streptomyces monashensis MUSC $1 \mathrm{~J}^{\mathrm{T}}$. Prog Drug Dis Biomed Sci 2019; 2(1).

46. Ser HL, Ab Mutalib NS, Yin WF, et al. Genome sequence of Streptomyces antioxidans MUSC $164^{\mathrm{T}}$ isolated from mangrove forest. Prog Microbes Mol Biol 2018; 1(1).

47. Ser HL, Tan WS, Ab Mutalib NS, et al. Genome sequence of Streptomyces mangrovisoli MUSC $149^{\mathrm{T}}$ isolated from intertidal sediments. Braz J Microbiol 2018; 49(1): 13-15.

48. Ser HL, Tan WS, Cheng HJ, et al. Draft genome of starch-degrading actinobacterium, Microbacterium mangrovi MUSC $115^{\mathrm{T}}$ isolated from intertidal sediments. Prog Drug Dis Biomed Sci 2018; 1(1).

49. Letchumanan V, Ser HL, Tan WS, et al. Genome sequence of Vibrio parahaemolyticus VP152 strain isolated from Penaeus indicus in Malaysia. Front Microbiol 2016; 7: 1410

50. Aziz RK, Bartels D, Best AA, et al. The RAST Server: rapid annotations using subsystems technology. BMC Genomics 2008; 9: 75.

51. Tatusova T, DiCuccio M, Badretdin A, et al. NCBI prokaryotic genome annotation pipeline. Nuc Acids Res 2016; 44(14): 6614-6624.

52. Lowe TM and Eddy SR. tRNAscan-SE: a program for improved detection of transfer RNA genes in genomic sequence. Nuc Acids Res 1997; 25: 955-964.

53. Lagesen K, Hallin P, Rodland EA, et al. RNAmmer: consistent and rapid annotation of ribosomal RNA genes. Nuc Acids Res 2007; 35: $3100-3108$

54. Hyatt D, Chen GL, Locascio PF, et al. Prodigal: prokaryotic gene recognition and translation initiation site identification. BMC Bioinform 2010; 11: 119 .

55. Blin K, Wolf T, Chevrette MG, et al. antiSMASH 4.0-improvements 
in chemistry prediction and gene cluster boundary identification. Nuc Acids Res 2017; 45(W1): W36-41.

56. Blin K, Shaw S, Steinke K, et al. antiSMASH 5.0: updates to the secondary metabolite genome mining pipeline. Nuc Acids Res 2019; 47(W1): W81-87.

57. Lv H, Liu J, Wang L, et al. Ameliorating effects of combined curcumin and desferrioxamine on 6-OHDA-induced rat mode of Parkinson's disease. Cell Biochem Biophysics 2014; 70(2): 1433-1438.

58. Christen Y. Oxidative stress and Alzheimer disease. Amer J Clin Nutri 2000; 71(2): 621S-629S.

59. Salis O, Bedir A, Kilinc V, et al. The anticancer effects of desferrioxamine on human breast adenocarcinoma and hepatocellular carcinoma cells. Cancer Biomarkers 2014; 14(6): 419-426.

60. Saad SY, Najjar TA and Al-Rikabi AC. The preventive role of deferoxamine against acute doxorubicin-induced cardiac, renal and hepatic toxicity in rats. Pharmacol Res 2001; 43(3): 211-218.

61. Hann HW, Stahlhut MW and Blumberg BS. Iron nutrition and tumor growth: decreased tumor growth in iron-deficient mice. Cancer Res 1988; 48(15): 4168-4170

62. Heath JL, Weiss JM, Lavau CP, et al. Iron deprivation in cancerpotential therapeutic implications. Nutrients 2013; 5(8): 2836-2859.

63. Xue $X$ and Shah YM. Intestinal iron homeostasis and colon tumorigenesis. Nutrients 2013; 5(7): 2333-2351.

64. Akam EA and Tomat E. Targeting iron in colon cancer via glycoconjugation of thiosemicarbazone prochelators. Bioconjugate Chem 2016; 27(8): 1807-1812.

65. Prutki M, Poljak-Blazi M, Jakopovic M, et al. Altered iron metabolism, transferrin receptor 1 and ferritin in patients with colon cancer. Cancer Lett 2006; 238(2): 188-196.

66. Torti SV and Torti FM. Iron and cancer: more ore to be mined. Nature Rev Cancer 2013; 13(5): 342-355.

67. Wurzelmann JI, Silver A, Schreinemachers DM, et al. Iron intake and the risk of colorectal cancer. Cancer Epidemiol Prevent Biomarkers 1996; 5(7): 503-507.

68. Czech L, Hermann L, Stöveken N, et al. Role of the extremolytes ectoine and hydroxyectoine as stress protectants and nutrients: genetics, phylogenomics, biochemistry, and structural analysis. Genes 2018; 9(4): 177.

69. He YZ, Gong J, Yu HY, et al. High production of ectoine from aspartate and glycerol by use of whole-cell biocatalysis in recombinant Escherichia coli. Microbial Cell Factories 2015; 14(1): 55.

70. Bremer E, Richter AA, Mais CN, et al. Biosynthesis of the stressprotectant and chemical chaperon ectoine: biochemistry of the transaminase EctB. Front Microbiol 2019; 10: 2811.

71. Jebbar $\mathrm{M}$, von Blohn $\mathrm{C}$ and Bremer E. Ectoine functions as an osmoprotectant in Bacillus subtilis and is accumulated via the ABCtransport system OpuC. FEMS Microbiol Lett 1997; 154(2): 325-330.

72. Schwibbert K, Marin-Sanguino A, Bagyan I, et al. A blueprint of ectoine metabolism from the genome of the industrial producer Halomonas elongata DSM 2581 ${ }^{\mathrm{T}}$. Environ Microbiol 2011; 13(8): 1973-1994.

73. Hahn MB, Meyer S, Schröter MA, et al. DNA protection by ectoine from ionizing radiation: molecular mechanisms. Physical Chem Chem Physics 2017; 19(37): 25717-25722.

74. Rieckmann T, Gatzemeier F, Christiansen S, et al. The inflammationreducing compatible solute ectoine does not impair the cytotoxic effect of ionizing radiation on head and neck cancer cells. Sci Rep 2019; 9(1): $1-8$.

75. Brands S, Schein P, Castro-Ochoa KF, et al. Hydroxyl radical scavenging of the compatible solute ectoine generates two N-acetimides. Arch Biochem Biophysics 2019; 674: 108097.

76. Shaikhpour M, Sadeghi A, Yazdian F, et al. Anticancer and apoptotic effects of ectoine and hydroxyectoine on non-small cell lung cancer cells: an in-vitro investigation. Multidis Cancer Invest 2019; 3(2): 14-19.

77. Bownik A and Stępniewska Z. Ectoine as a promising protective agent in humans and animals. Arch Indust Hygiene Toxicol 2016; 67(4): 260-265.

78. Takano H, Matsui Y, Nomura J, et al. High production of a class III lantipeptide AmfS in Streptomyces griseus. Biosci Biotech Biochem 2017; 81(1): 153-164.

79. Knerr PJ and Van der Donk WA. Discovery, biosynthesis, and engineering of lantipeptides. Ann Rev Biochem 2012; 81: 479-505.

80. Belknap KC, Park CJ, Barth BM, et al. Genome mining of biosynthetic and chemotherapeutic gene clusters in Streptomyces bacteria. Sci Rep 2020; 10 .

81. Iniyan AM, Sudarman E, Wink J, et al. Ala-geninthiocin, a new broad spectrum thiopeptide antibiotic, produced by a marine Streptomyces sp. ICN19. J Antibiotics 2019; 72(2): 99-105.

82. Yu Y, Zhang Q and Van Der Donk WA. Insights into the evolution of lanthipeptide biosynthesis. Protein Sci 2013; 22(11): 1478-1489.

83. Piper C, Cotter PD, Ross RP, et al. Discovery of medically significant lantibiotics. Curr Drug Dis Technol 2009; 6(1): 1-8.

84. Schneider O, Simic N, Aachmann FL, et al. Genome mining of Streptomyces sp. YIM 130001 isolated from lichen affords new thiopeptide antibiotic. Front Microbiol 2018; 9: 3139.

85. Chen E, Chen $\mathrm{Q}$, Chen $\mathrm{S}$, et al. Mathermycin, a lantibiotic from the marine actinomycete Marinactinospora thermotolerans SCSIO 00652. Appl Environ Microbiol 2017; 83(15).

86. Foulston LC and Bibb MJ. Microbisporicin gene cluster reveals unusual features of lantibiotic biosynthesis in actinomycetes. Proc Nat Acad Sci 2010; 107(30): 13461-13466.

87. Liu R, Deng Z and Liu T. Streptomyces species: Ideal chassis for natural product discovery and overproduction. Metabolic engineering. 2018; 50: $74-84$.
88. Nah HJ, Pyeon HR, Kang SH, et al. Cloning and heterologous expression of a large-sized natural product biosynthetic gene cluster in Streptomyces species. Front Microbiol 2017; 8: 394. 